Article

\title{
The Middle Lamella of Plant Fibers Used as Composite Reinforcement: Investigation by Atomic Force Microscopy
}

\author{
Alessia Melelli ${ }^{1, *(\mathbb{C}}$, Olivier Arnould ${ }^{2}{ }^{\mathbb{D}}$, Johnny Beaugrand ${ }^{3}$ and Alain Bourmaud ${ }^{1}(\mathbb{D}$ \\ 1 IRDL, Université de Bretagne Sud, UMR CNRS 6027, 56321 Lorient, France; alain.bourmaud@univ-ubs.fr \\ 2 LMGC, Université de Montpellier, CNRS, 34095 Montpellier, France; olivier.arnould@umontpellier.fr \\ 3 INRAE, UR1268 BIA Biopolymères Interactions Assemblages, 44316 Nantes, France; \\ johnny.beaugrand@inra.fr \\ * Correspondence: alessia.melelli@univ-ubs.fr; Tel.: +33-297-874-518
}

Academic Editors: Pietro Russo and Fabrizio Sarasini

Received: 20 December 2019; Accepted: 29 January 2020; Published: 1 February 2020

\begin{abstract}
Today, plant fibers are considered as an important new renewable resource that can compete with some synthetic fibers, such as glass, in fiber-reinforced composites. In previous works, it was noted that the pectin-enriched middle lamella (ML) is a weak point in the fiber bundles for plant fiber-reinforced composites. ML is strongly bonded to the primary walls of the cells to form a complex layer called the compound middle lamella (CML). In a composite, cracks preferentially propagate along and through this layer when a mechanical loading is applied. In this work, middle lamellae of several plant fibers of different origin (flax, hemp, jute, kenaf, nettle, and date palm leaf sheath), among the most used for composite reinforcement, are investigated by atomic force microscopy (AFM). The peak-force quantitative nanomechanical property mapping (PF-QNM) mode is used in order to estimate the indentation modulus of this layer. AFM PF-QNM confirmed its potential and suitability to mechanically characterize and compare the stiffness of small areas at the micro and nanoscale level, such as plant cell walls and middle lamellae. Our results suggest that the mean indentation modulus of ML is in the range from $6 \mathrm{GPa}$ (date palm leaf sheath) to $16 \mathrm{GPa}$ (hemp), depending on the plant considered. Moreover, local cell-wall layer architectures were finely evidenced and described.
\end{abstract}

Keywords: biocomposite; plant fibers; middle lamella; AFM PF-QNM; nanomechanical characterization

\section{Introduction}

In the last few decades, plant fiber-reinforced composites were progressively developed to replace composites where synthetic fibers are usually used or, in some cases, to create new families of composites having specific properties [1]. Their cost-effective production, low environmental impact, and specific mechanical properties, almost comparable to those of glass fibers, encourage industries to invest in this area $[2,3]$.

Many plant species in nature produce fibers that can be employed for this purpose, but their structure, chemical composition, and properties differ greatly and depend on the type of plant [4-6]. An exhaustive summary of the plant fibers used for composite materials can be found in Reference [7], where they are divided into wood and non-wood (e.g., bast), based on their location inside the plant. Bast fibers have high cellulose content, low microfibrillar angle (MFA), and consequently high mechanical performances in the fiber axis (or longitudinal) direction. Thus, they play a central role in new biocomposites, especially compared to leaf, xylem, or mesocarp fibers, and a clear example can 
be found in Wambua et al. [8]. The authors studied several poly-(propylene) composites reinforced with different plant fibers (sisal, kenaf, jute, hemp, and coir), and their results showed that coir fibers, extracted from seeds, have lower longitudinal mechanical properties than the others but, on the other hand, they exhibit a higher impact strength, which was also confirmed in Reference [9]. This result follows the functional evolution of the different kinds of cells in a plant; for example, bast fibers are responsible for the stiff structure of a plant and this specific role also explains their high mechanical performance.

Every bast fiber has a similar (ultra)structural model even if they originate from different plants. An elementary fiber is a single cell, and several fibers are linked to each other to form a bundle of several dozens of single fibers having a multilayer structure, as illustrated in Figure 1a: (1) the lumen is the central hollow part of the cell and its shape and diameter vary with the maturity of the plant and the environmental conditions during growth; (2) the secondary cell wall is the thickest layer, divided into two to three sub-layers $\left(S_{1}, S_{2}\right.$ or $G$, and $\left.S_{3}\right)$ rich in cellulose where the thinner and not always visible $S_{3}$ can also be assimilated to unmatured $G$ layer instead of a real $S_{3}$ [10]; (3) the primary cell wall is the external layer enriched in hemicelluloses, pectins, and lignin [11]. Between the fibers, there is another layer called middle lamella (ML), which cements the primary cell walls of adjacent cells together and is mainly composed of pectic polysaccharides, lignin, and a small amount of proteins [12-14]. This binder layer between two cells acts as a very thin and efficient interfacial matrix in the plant $[13,15]$.

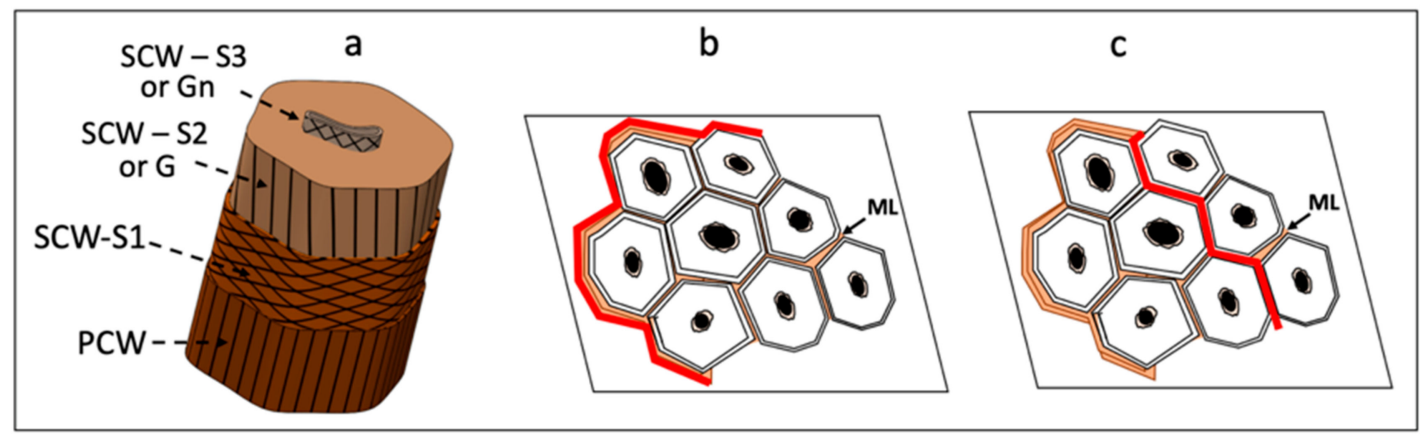

Figure 1. Diagrams illustrating the structural arrangement of a single flax fiber (a) and a crack (in red) that (b) propagates along the perimeter of a bundle and (c) through the bundle in a plant fiber-reinforced thermoset composite under tensile tests. SCW $S_{1}, S_{2}$ or $G, S_{3}$ or $G n=$ secondary cell wall, $\mathrm{PCW}=$ primary cell wall, $\mathrm{ML}=$ middle lamella.

Despite this complex hierarchical structure, the $S_{2}$ is the most important layer and the main contributor to the longitudinal mechanical properties of a single fiber due to its thickness and ultra-structure. Consequently, it is also the layer most responsible for the mechanical behavior of a final product when plant fibers are used as reinforcements in composite materials. The conventional interface level between polymer matrix and plant fibers, which often coincides with the secondary wall, was deeply investigated. However, middle lamellae have a strong presence in plant fiber composite materials due to the specific arrangement of the fibers into bundles in planta. Their amount depends not only on retting and extraction conditions but also on the material processing conditions that influence the shear rate and the temperature experienced by the fibers during composite processing [16-18].

Some studies demonstrated how this layer plays a central role in the mechanical behavior of the final product. Bourmaud et al. [19] noted several failure mechanisms for plant fiber biocomposite materials, and Monti et al. [20] showed that, in thermoset composites, cracks often propagate around the fiber bundles and through them, as illustrated in Figure 1. Recently, in Reference [21] results showed that middle lamellae constitute an area of failure and that their behavior is strongly related to their properties and cohesion with the fibers.

For a correct computational modeling of the plant fibers, the plant fiber bundles, and the biocomposite mechanical behavior, numerical values of mechanical properties of the middle lamella 
are required [22]. Some attempts were made to measure the mechanical properties of the ML of onion or flax cells using tensile tests $[23,24]$, but this kind of test remains challenging and difficult to interpret. Due to its reduced thickness in the order of the sub-micron, most of the measurements were done using micromechanical characterization techniques, such as nanoindentation in the cell corner middle lamella (CCML); however, to our best knowledge, they are mainly limited to some wood samples [25-28]. In these cases, the average indentation modulus obtained ranges from around 5 to $11 \mathrm{GPa}$ but with a generally high standard deviation.

On the other hand, atomic force microscopy (AFM) was already used to investigate the middle lamellae [28]. However, even if this technique is suitable for performing mechanical measurements in areas at the nanoscale level like the CML layer, to our best knowledge, available data are scarce and limited to the middle lamella of wood using contact resonance-AFM (CR-AFM) [29,30] or AFM peak-force quantitative nanomechanical property mapping (PF-QNM) [31] with an average value ranging from 6 to $17 \mathrm{GPa}$, and of bamboo, using AFM PF-QNM [32], with an average value around 14 GPa [31]. These two kinds of measurements, i.e., nanoindentation and almost all the mechanical AFM methods, give access to the indentation modulus that depends on all the elastic constants of the material (Young's moduli, shear moduli, and Poisson's ratios) in a complex manner for an anisotropic behavior like the secondary cell-wall layers [33,34]. However, in this case, as there are no microfibrils in the middle lamella and its structure is quite random, the ML is usually considered to have an isotropic elastic behavior [35] and the indentation modulus only depends on one Young's modulus and one Poisson's ratio.

Until now, few experimental data on its independent elastic properties are available, and only an estimate of the elastic properties of each component extracted from the middle lamella is known. On the contrary, their biochemical composition is quite well documented in the literature. To our best knowledge, only Zamil et al. [23] tried to measure its tensile properties in onion, and they obtained mean values of the Young's modulus ranging from around 8 to $11 \mathrm{GPa}$. In the case of an isotropic material, the indentation modulus $M$ can be expressed according to the Hertz formula, $M=E /\left(1-v^{2}\right)$, where $E$ is the Young's modulus and $v$ is the Poisson's ratio. The Poisson's ratio of the middle lamella is not known but it should be lower than 0.5 like most amorphous polymer blends. Thus, in this case, the indentation modulus is quite close to the Young's modulus.

In previous papers, a protocol to study the mechanical properties of plant cells with the AFM PF-QNM method was already tested and the results were validated [36-39]. In the present work, AFM PF-QNM was used to investigate the area of the middle lamellae at the cell-wall level and to obtain information on their indentation modulus. For that purpose, a panel of plant fibers commonly used in biocomposites, i.e., flax, hemp, jute, kenaf, nettle, and date palm leaf sheath, was investigated. A database of middle lamella indentation modulus was addressed on this range of plant fibers to implement the knowledge of this layer and help future works in computational modeling.

\section{Results and Discussion}

Figure 2 shows the topography and indentation modulus mapping obtained through AFM PF-QNM measurement of flax, nettle, jute, kenaf, hemp, and date palm fibers. These images not only provide values of the indentation modulus but also information about the morphology of the middle lamellae. In References [40,41], the authors made a distinction between the middle lamella (ML) and the compound middle lamella (CML), especially referring to the wood samples, but this distinction is also applicable to other plant fibers [13]. In fact, the middle lamella between two primary walls of two different cells is often not distinguishable [13], and the small tripartite layer appears as a single layer, such as in Figure $2 b$ or Figure $2 d$. For this reason, in the present paper, the indentation modulus is measured in the tricellular junctions, usually called the cell corner middle lamella (CCML), where the middle lamella is well discernible. However, it should be taken into account that the biochemical composition of the CCML may differ from the ML [13]. 

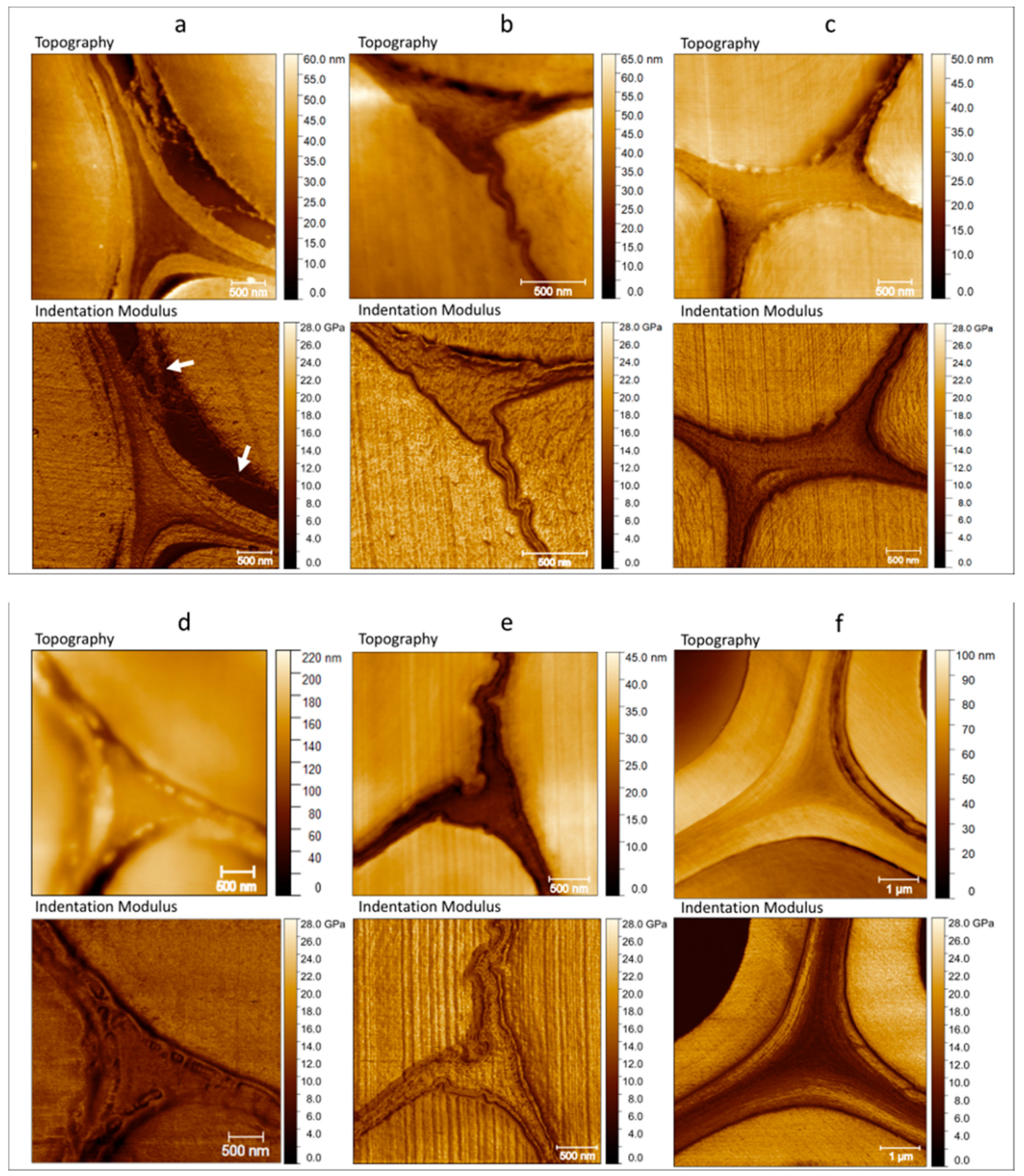

Figure 2. Topography (top) and indentation modulus (bottom) of the cell corners of (a) flax with illustration of decohesion (highlighted with white arrows) between $S_{1}$ and $S_{2}$ layers, (b) nettle with values of indentation modulus close to those of the cell wall, (c) jute, (d) kenaf, (e) hemp with the highest indentation modulus, and (f) date palm tree with the lowest indentation modulus but with a homogeneous and thick area for the middle lamella.

In Figure 2a, flax shows an interesting fracture (decohesion highlighted with white arrows), which probably occurred between the secondary $S_{2}$ and $S_{1}$ cell wall layers during the handling of the green flax stem. In several other images of the same section of the flax stem, other cells showed this kind of fracture between $S_{1}$ and $S_{2}$ secondary layers, which was previously noted by Arnould et al. [39] and Goudenhooft et al. [38]. In addition, from Day et al.'s (2005) [42] pictures, it is possible to identify fractures, which occurred at the CML- $S_{1}$ or $S_{1}-S_{2}$ level and their observations are in line with our results and conclusions. Le Duigou et al. [43] also observed peeling failures of the external fiber layer of flax fibers during a microdroplet debonding test, proving the low cohesion degree between structural layers. 
In addition, the images collected confirm the observations done by Zamil and Geitmann [13] and Raghavan et al [15] in the $M L$ and $S_{1}-S_{2}$ region. The authors reported that the middle lamella is stronger than the primary or secondary wall layers and not damaged from a mechanical stretch; on the contrary, fractures take place in the adjacent primary or secondary cell-wall layers. This fact reinforces the generally accepted assumption in the plant fiber community that the mechanical behavior of the ML is far from the brittle behavior associated with the cell-wall layers. Middle lamellae in flax are well distinguishable and with an indentation modulus clearly lower than the other cell-wall layers, as can be expected given that this layer has a random organization and constitutes non-cellulosic polymers. For the same variety of flax investigated by our team [36,38], a similar contrast was highlighted between values of indentation modulus obtained in $S_{2}$ and $M L$, even if measurements were done at a larger scale and not especially dedicated to the investigation of the ML. Possible differences in thickness or arrangement of the ML area can be due to the position of the fibers inside the same plant. In fact, one can find changes in the lumen, the cell, and the size of the middle lamella according to the considered stem cross-section along the height of the stem [44].

Nettle is reported in Figure $2 b$, and its middle lamella clearly shows a high indentation modulus, almost comparable to the surrounding cell walls. In general, the indentation modulus is highly influenced by the anisotropic character of the considered material; thus, in this case, of quasi isotropic non-cellulosic polymer (NCP) middle lamellae, the indentation modulus can be in the same range as the $S_{2}$, which is underestimated due to the highly anisotropic nature of the secondary cell wall [33]. However, the indentation modulus in the middle lamella is remarkably high here and could be linked to a specific biochemical composition that must be investigated.

The indentation modulus in the middle lamella is globally homogeneous, but one can note small areas where the indentation modulus is lower and other areas where it is higher, creating an irregular matrix like a grid or globular aspect. Considering the size of these nodules, of a few tens of nanometers (Figure A1, Appendix A, where zoomed-in view of the ML region are shown, not corrected for the effect of tip dilation), they might be attributed to the lignin $[31,45,46]$, but the variations of the modulus measured in that area are more likely due to a topographic effect. As the roughness in that area is similar to the tip radius, it induces a strong correlation between the topography and the indentation modulus (Figure A1, Appendix A), which induces an apparently higher indentation modulus between two nodules and a lower one on top of them [47]. Bourmaud et al. [36] hypothesized that the degree of lignification is an important factor in the middle lamella morphology; however, although it is known in the literature that this layer is enriched in lignin, a direct quantification remains a challenge because of its sub-micrometric scale. In addition, in nettle, as previously mentioned, the primary cell wall is not well distinguishable from the middle lamellae, and they appear as a single unitary layer between two fibers.

On the other hand, the middle lamellae of jute fibers are clearly distinguishable from the surrounding cell walls (Figure 2c) thanks to their lower indentation modulus. In addition, the indentation modulus in CCML appears homogeneous with a fine texture that does not represent disconnections or asperities when compared with those of nettle. However, one can note that, in jute, there is a small difference between the indentation modulus of the central area of the CCML and its edge (Figure 3) that is not due to an effect of topography. The indentation modulus gradually increases from the edge to the center of the tricellular junction; this singular phenomenon was noted on each jute CCML investigated but not for other middle lamellae investigated in the present paper, such as nettle and palm sheath fibers. The AFM PF-QNM method, thanks to its high resolution, is able to clearly highlight this kind of gradient in a restricted area (Figure 3), confirming its potential for ultra-local mechanical investigations. 


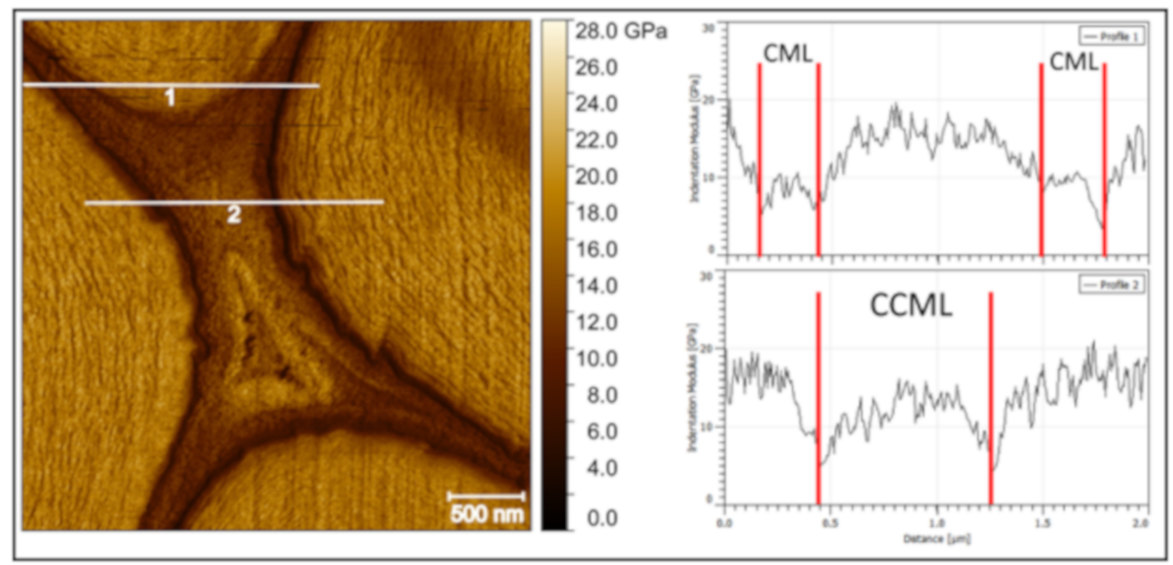

Figure 3. Middle lamella cell corner in jute fibers. Two profiles (in white) are marked on the indentation modulus mapping, and graphics extracted are shown on the right. The middle lamella cell corner (CCML) shows an increment of the values of indentation modulus from the edge, near the fiber cells, to the core.

In Figure $2 \mathrm{~d}$, the primary walls of kenaf fibers show strong inhomogeneities with a highly globular aspect. In the present case, even more than in the case of nettle, the topography of the nodules induces a strong effect on the apparent indentation modulus. Moreover, the distinction of the middle lamella and the primary walls is difficult compared to other plant fibers. The origin of these nodules is not clear but might be linked to the cutting behavior and, therefore, to the mechanical properties of the different components of the cell wall layers during the sample surface preparation. Softer components make them harder to cut and leads to more irreversible deformation when cutting. These differences in behavior induce variations in topography $[29,48]$ such as steps between layers of the cell wall (as between $S_{1}$ and $S_{2}$ or between $S_{2}$ and the embedding resin) and roughness or nodules, as in the case of lignin, within a layer. However, biochemical investigations, like Raman spectroscopy, must be done to better understand this phenomenon.

Figure 2e illustrates a tricellular junction between three hemp fibers. The middle lamella of hemp, together with the nettle, shows the highest values of indentation modulus that are also well correlated with values found by Bourmaud et al. [36] on several plant fibers studied by AFM PF-QNM mode. Nevertheless, in both nettle and hemp, not only the middle lamella but also the indentation modulus of hemp and nettle fiber cell walls are high. The matrix inside the middle lamella of hemp is similar to the grid texture that was observed in nettle; however, in addition to this morphology and contrarily to the nettle, the primary cell wall is clearly distinguishable from the ML.

In Figure 2f, date palm CCML is demonstrated to have the lowest values and an extreme homogeneity of the indentation modulus with a clear separation of the layers from each other. This is especially visible in Figure 4 where the middle lamellae of kenaf and date palm fibers are compared and underlined. Both graphical representations and distributions of the indentation modulus (Figure 4c) underline significant differences in terms of indentation modulus between the two plants considered.

In kenaf, the non-uniformity of color mapping clearly shows discontinuities with higher and lower values of the indentation modulus. These heterogeneities are partly due to a topography effect of the mechanical measurements caused by the huge globular aspect of the primary wall and possibly due to the cutting effects during the sample preparation between cell-wall layers or within a layer. On the other hand, the indentation modulus in the date palm middle lamella is more uniform, although the surface area analyzed is larger than that for kenaf. 


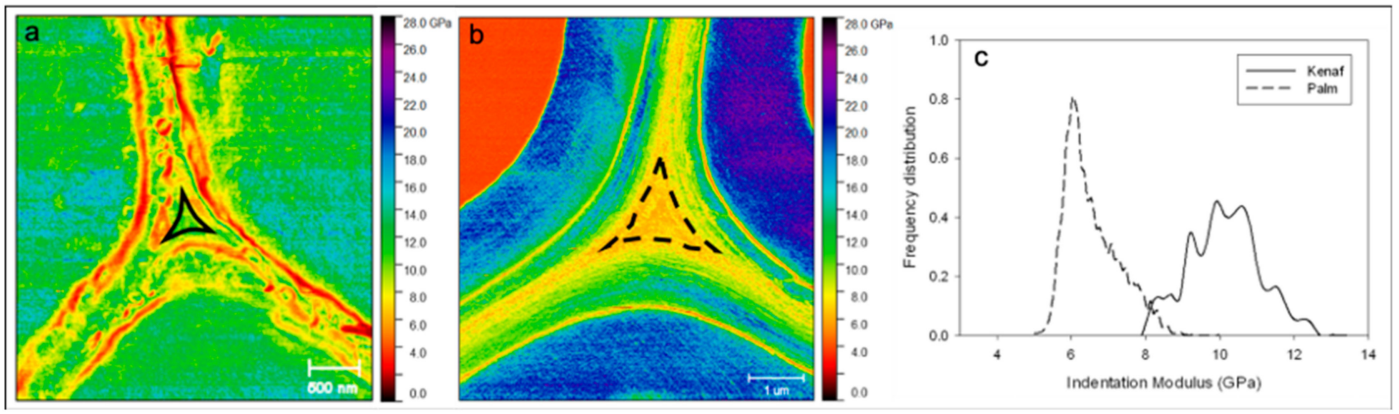

Figure 4. (a) Kenaf middle lamella where a non-uniform distribution is clearly visible; (b) date palm middle lamella with a more uniform indentation modulus distribution inside the middle lamella of the tricellular junction; (c) distribution of indentation modulus in middle lamella area of kenaf and palm, showing a high difference in the spread of values. For kenaf and date palm, the area investigated is highlighted in (a) and (b) using solid and dotted black lines, respectively.

For some fibers such as flax and palm, it is possible to trace and identify all the layers present in the fiber bundles, which are underlined thanks to their different modulus in Figure 5, highlighting the typical hierarchical structure.

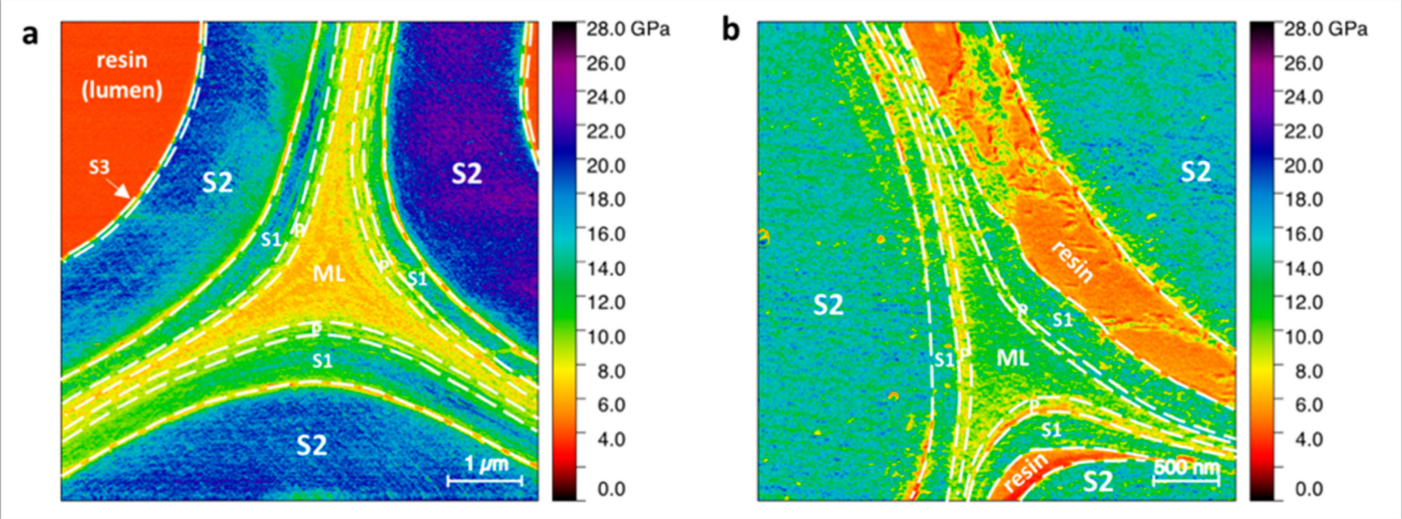

Figure 5. (a) Date palm leaf sheath and (b) flax middle lamella area; limits between layers are clearly identified and highlighted by dotted lines.

Average numerical values of the indentation modulus calculated in a selected area of each middle lamella are summarized in Figure 6 and Table 1 with their respective standard deviation.

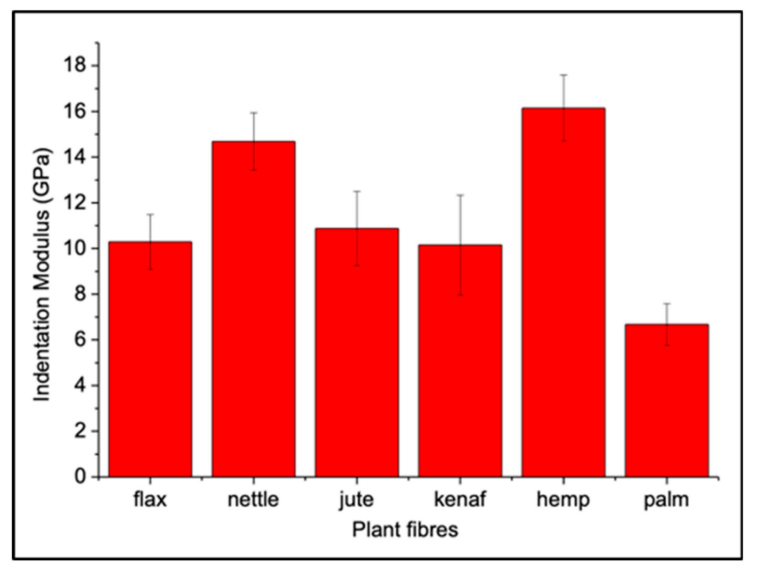

Figure 6. Average values of indentation modulus calculated in each plant fiber middle lamella considered and respective standard deviation bars. 
Table 1. Average and standard deviation of the indentation modulus obtained on the middle lamella of the panel of plant fibers considered.

\begin{tabular}{cc}
\hline \multicolumn{2}{c}{ Indentation Modulus (GPa) } \\
\hline $\begin{array}{c}\text { Linum Usitatissimum L. } \\
\text { (Flax) }\end{array}$ & $10.2( \pm 1.2)$ \\
$\begin{array}{c}\text { Cannabis Sativa } \\
\text { (Hemp) }\end{array}$ & $16.1( \pm 1.4)$ \\
Corchorus capsularis \\
$\begin{array}{c}\text { (Jute) } \\
\text { Hibiscus cannabinus } \\
\text { (Kenaf) }\end{array}$ & $10.9( \pm 1.6)$ \\
$\begin{array}{c}\text { Urtica Doïca } \\
\text { (Nettle) }\end{array}$ & $10.2( \pm 2.2)$ \\
$\begin{array}{c}\text { Phoenix dactylifera } \\
\text { (Date palm leaf sheath) }\end{array}$ & $6.7( \pm 0.9)$ \\
\hline
\end{tabular}

As previously mentioned, kenaf has the highest standard deviation since these measurements reflect the important inhomogeneity (see Figure 4a) of the CCML region. Nevertheless, average values from flax, jute, and kenaf are comparable. Hemp and nettle have the highest indentation modulus for the middle lamellae. The morphology of these two ML is similar, probably because of the presence of a large amount of lignin. On the other hand, palm fiber CCML regions show the lowest indentation modulus.

The different origin of the fiber elements is also visible in their overall chemical composition (Table 2), which is related to their botanical functions or roles for the plant. Among the six plant species considered, some fibers ensure the role of conduction of raw or elaborated sap, and others have the function of supporting the stem and ensure its stability. For example, kenaf fibers are located in the bast (cortical layer) and core (woody) region. The bast fibers constitute around $40 \%$ of the total amount of the fibers. Primary phloic fibers (PPF) from procambium in the protophloem region and secondary phloic fibers (SPF) from cambium are both developed in both jute [49] and kenaf. Thus, in these two plants, the chemical composition of the fibers is highly dependent on the tissue from which they come. This kind of cellular heterogeneity, coming from the tissue origin, does not exist for flax and nettle, which have gelatinous and poorly lignified fibers that can be extracted only from the primary phloem region. In the case of hemp, a possible mix between primary and secondary fibers may occur; these two kinds of fibers have a role in the mechanical support of the plant. Consequently, their compositions and mechanical properties are fairly similar and the main difference is the length, which is significantly shorter for the secondary fibers because of their delayed growth that occurs after the structuration of the tissues.

For flax, hemp, and jute, middle lamellae are often reported as lignin-enriched domains, which are often highlighted to explain the mechanical stiffness and cohesion of the fiber bundles employed as composite reinforcement. Nevertheless, cell-wall lignification generally appears after seed maturity and, according to the cultivation management, can be strongly limited. For flax pulled out after flowering or seed maturity, Day et al. [42] reported a low lignin labeling in the CML area, absent in the cell corner and tricellular junctions, regardless of the epitope considered. Flax samples investigated in our paper come from the plant stem and they were collected before the lignification of the middle lamella; in addition, no retting or scutching processes were performed contrary to the hemp fibers. In this case, the lignification and the retting effect could explain the higher indentation modulus of hemp fibers than of flax.

As previously reported, the amount of lignin and the quality of links between the several layers influence the behavior of the fiber bundles and, in the specific case of flax where decohesion between CML- $S_{1}$ or $S_{1}-S_{2}$ level is noted, our results are in line with the figure reported in Reference [42]. These damages at the level of the middle lamella also have an impact on the biocomposite material when flax fibers are used as reinforcement. A second polymer well known to be an influent actor of the cell 
cohesion is the pectin family, precisely located in the ML. It was demonstrated that the mechanical properties of the ML may vary with the degree of the esterified form of homogalacturonan [50]. This pectin is then more or less able to generate interchain interactions, for instance, by calcium cross-linking, if homogalacturonans are de-esterified. From our panel of phenotype samples, the backbone of the pectin methylation degree is arguably different, and some contrasted mechanical properties can be, therefore, expected due to susceptibility to cross-linking.

Dhakal et al. [37] investigated the damage mechanisms after impact testing for palm/PCL composites and they reported that, even after testing, the morphology of the date palm bundles remained unaltered. This is due to the high content in lignin and the homogeneity of the middle lamella (Figure 2f) that strongly links the single palm fibers together, more than in other plant fibers, despite a soft middle lamella (Figure 6 \& Table 1). The silica-reinforced external paravascular or parafibrovascular parenchyma of bundles [51] is arguably too strong to be damaged, even after a high shear-rate process. In Reference [52], opposite results were highlighted on flax bundles and significant cracks were visible after transverse tensile tests on the CML area. Indeed, the individualization of the fibers can be more or less pronounced, according to the process used to produce the composite material [18] and the scutching or hackling degree of the fibers [53] during the fiber extraction process. Consequently, all these factors can introduce significant changes in the mechanical performance of the final composite. In addition, when the composite contains a large number of flax fiber bundles, one can notice that, during loading, the damages occur preferably in the bundles, especially in the CML area $[19,20]$. In this case, the fiber-matrix interface is not the most critical, even when the polyolefin matrix, with a weak fiber-matrix interface, is used. Thus, even if the indentation modulus of flax ML is higher than the palm one (Table 1), the individualization of flax fibers is facilitated thanks to the specific organization of the bundles and preliminary action of retting and scutching. However, as reported in Reference [13], ML in flax are not directly involved in the failures, but the weak area seems to be between the different layers $\left(S_{1}-S_{2}\right)$ and not inside the middle lamella, even if ML exhibits a lower stiffness. A hypothesis for this result is that the softness and the cohesion of the ML are probably an advantage for the energy dissipation, and they limit the cell-wall damage during mechanical loading or shear rate stress. To support that assumption, a parallel can be done with the nacre, where the microstructure displays some homologies with the lignocellulosic bundles. Indeed, stiff and large structures of ceramic, as the fiber cell wall in our study, are embedded in a thin and weak mortar made of unfolded proteins and chitin biopolymers. The latter is the middle lamella of the bundles. During loading, in the nacre, the thin interface is able to deform, with most of the fracture occurring at the interfaces, providing more inelastic regions and favoring more energy dissipation and higher work of fracture, thereby giving nacre an elevated damage tolerance [54].

In our plant samples, palm sheath fibers, which have CCML with a lower indentation modulus, are probably less damaged in contrast to the flax fibers.

On the other hand, if we consider the jute fibers, it is clear that they have an indentation modulus similar to flax as reported in this paper (see Table 1), but their mechanical behavior inside a composite material is very different. This is probably due to their high lignin content, as well as to their short length, and, as a consequence, high volume content of middle lamellae. The cohesion in bundles is strong, inducing a specific behavior and a flow orientation in extrusion or injection molding [55]. Moreover, a high lignification is in favor of a good fiber-matrix interface, and Graupner et al. [56] noted that lignin may be an interesting adhesion promoter. Thus, flax, jute, and kenaf have similar CML indentation modulus (Table 1), but their mechanical and morphological behavior differs widely.

Finally, other fibers, such as hemp, have a strong tendency to be divided or fibrillated during the composite production process. This phenomenon was highlighted in extruded or injected compounds [57-59]. Interestingly, the difference between CML and $S_{2}$ modulus is lower for hemp compared to other plants, and this might introduce a strong link between these two layers, whereby a weaker interface could possibly be identified at the intra $S_{2}$ layer level. 
Table 2. Literature review of the biochemical global composition of the bundles of fibers studied, not reflecting the specific ML compositions.

\begin{tabular}{ccccc}
\hline & Cellulose (\%) & Hemicellulose (\%) & Lignin (\%) & Reference \\
\hline $\begin{array}{c}\text { Linum Usitatissimum L. } \\
\text { (Flax) }\end{array}$ & $60-85$ & $14.0-20.6$ & $1-3$ & {$[60-62]$} \\
$\begin{array}{c}\text { Cannabis Sativa } \\
\text { (Hemp) }\end{array}$ & $55-90$ & 12 & $2-5$ & {$[63-66]$} \\
$\begin{array}{c}\text { Corchorus capsularis } \\
\quad \text { (Jute) }\end{array}$ & $58.0-71.5$ & $13.6-24.0$ & $11.8-16$ & {$[67,68]$} \\
$\begin{array}{c}\text { Hibiscus cannabinus } \\
\text { (Kenaf) }\end{array}$ & $52.0-61.2$ & $18.5-29.7$ & $12.9-16.1$ & {$[69-71]$} \\
$\quad \begin{array}{c}\text { Urtica Doïca } \\
\text { (Nettle) }\end{array}$ & $65.3-86.3$ & $5.2-12.5$ & $1.6-3.8$ & {$[72]$} \\
$\quad$ Phoenix dactylifera \\
(Date palm leaf sheath)
\end{tabular}

Nevertheless, it is important to keep in mind that the morphology of the fibers may be involved in the breaking mechanism, and that the length of fibers and the ratio between the cell wall and lumen area may affect the critical shear rate, leading to irreversible damage. In addition, the indentation modulus is not necessarily correlated to the structural cohesion between layers, and the hardness investigated by the nano-indentation technique can be a better indicator even though it has a lower resolution than AFM PF-QNM. It is interesting to note that Wimmer et al. [28] studied the relationship between the longitudinal indentation modulus and hardness of CCML and $S_{2}$ in spruce wood, and they found a strong relationship between the indentation modulus of the CCML with its hardness, i.e., stiffer denoting harder, unlike the $\mathrm{S}_{2}$. In this article, the indentation modulus of the CCML ranges from 4 to $12 \mathrm{GPa}$, whereas the hardness ranges from 0.12 to $0.47 \mathrm{GPa}$ with a mean value close to that of the $\mathrm{S}_{2}$. As the hardness depends on the inelastic behavior of a material, it is linked to its plastic behavior and property at break. If we assume that these results can be transposed here, it would mean that nettle and hemp fiber middle lamellae have a higher hardness in relation to a higher secondary wall longitudinal property, contrary to palm leaf sheath fibers. This seems to make sense mechanically, but needs to be confirmed by additional hardness measurements in our samples and mechanical strength tests of ML [23] or bioinspired films [31].

For this reason, our measurements revealed huge differences in the indentation modulus of the middle lamella according to the plants considered, but it is difficult to correlate them directly to the differences in their mechanical behavior or damage mechanisms when fibers are employed in biocomposites. In fact, these complex phenomena are impacted not only by the nature and cohesion of this middle lamella, but also by the morphology and the biochemical composition or structure of the fibers and bundles.

\section{Materials and Methods}

\subsection{Materials}

Various plant fibers were taken to represent three of the main groups of fibers used for biocomposite manufacturing as reported in Figure 7.

For flax (Linum Usitatissimum L.), stems of the Eden variety cultivated in the year 2015 (Terre de Lin, Normandy, France) were chosen and cut after the first ramification (120 days) [38]. The nettle (Urtica Dïoica) samples were harvested in Lorraine (France) in 2014 and stored at room temperature in darkness; then, fibers were manually extracted. Hemp fibers from plants cultivated in 2016 (Fedora 17 variety) in Bar-Sur-Aube (France) and field retted were chosen. Jute (Corchorus capsularis L) and kenaf (Hibiscus cannabinus L) fibers, provided by Derotex (Wielsbeke, Belgium), were grown in Bangladesh, and retted in water before being mechanically extracted from the stems; both were cultivated in 
2015 [36]. Date palm fibers (Phoenix dactylifera L.) were from Al-Ahsa (Eastern Province of Saudi Arabia), and the large bundle of the mesh surrounding the date palm tree stems were considered [51].

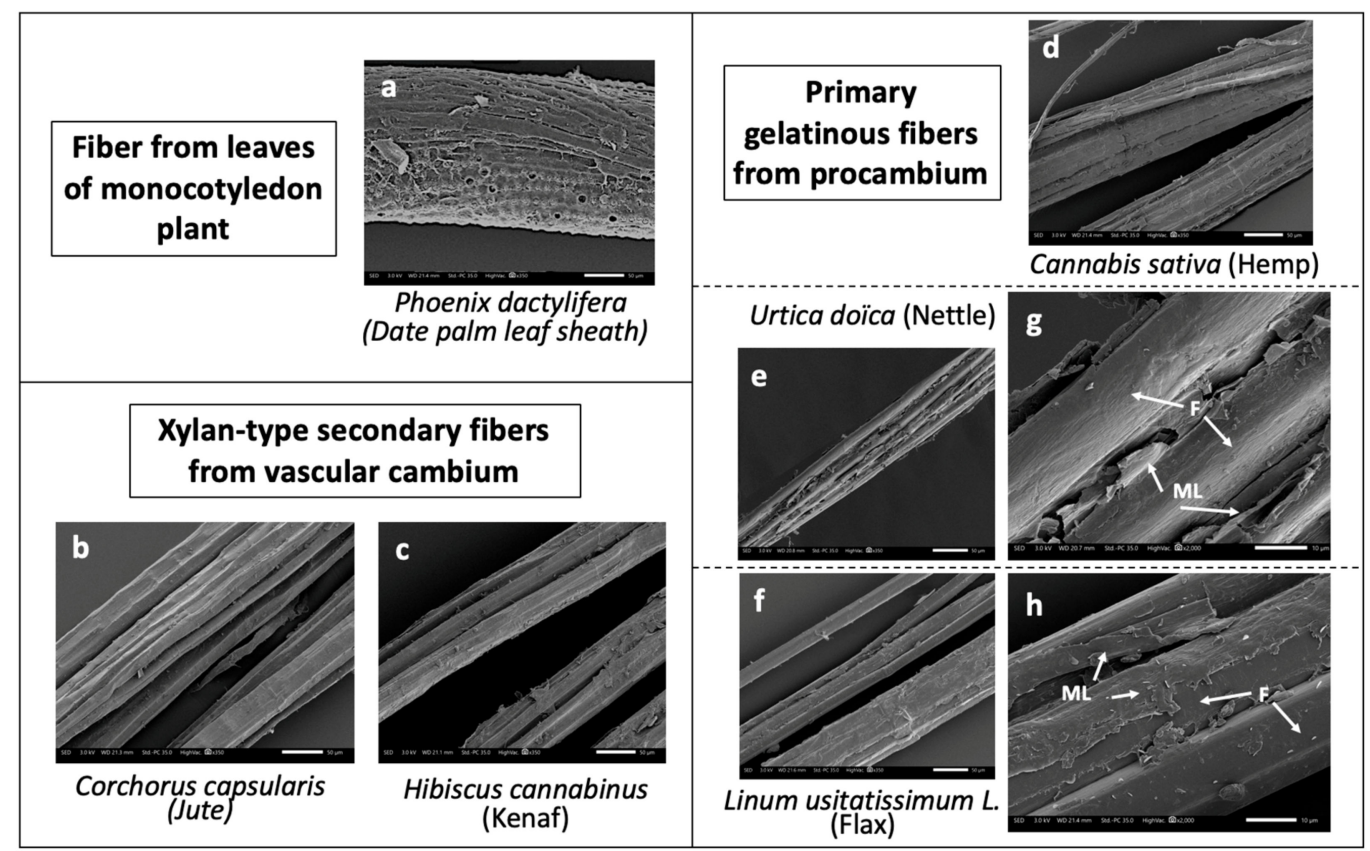

Figure 7. SEM images and classification of date palm leaf sheath (a), jute (b), kenaf (c), hemp (d), nettle (e), flax (f) fibers studied in this work. (g) and (h) are zooms on middle lamellae area of nettle and flax, respectively $(\mathrm{F}=$ fibers, $\mathrm{ML}=$ middle lamella). Scale bars correspond to $50-\mu \mathrm{m}$ lengths for all except $(\mathrm{g})$ and (h) $(10 \mu \mathrm{m})$.

All samples were dried $2 \mathrm{~h}$ in an oven at $60{ }^{\circ} \mathrm{C}$ to eliminate the moisture; then, they were dehydrated in a graded series of ethanol and included in London Resin (LR)-white acrylic resin. The final polymerization of the resin was made in the oven at $60^{\circ} \mathrm{C}$ overnight.

Embedded samples were then machined to reduce their cross-section to $1 \times 2 \mathrm{~mm}$, and an ultramicrotome (Ultracut R, Leica Microsystems SAS, Nanterre, France) with diamond knives (Histo and Ultra AFM, Diatome, Nidau, Switzerland) was used to cut a series of very thin sections (about $50 \mathrm{~nm}$ thick in the last step) at reduced cutting speed $(\sim 1 \mathrm{~mm} / \mathrm{s})$ to minimize compression and sample deformation during the cutting process. This preparation method resulted in much reduced surface roughness, which made it possible to obtain relevant AFM PF-QNM measurements.

\subsection{Methods}

A multimode atomic force microscope (Bruker) was equipped with a RTESPA-525 probe (Bruker AFM Probes, Camarillo, CA, USA) for the PF-QNM analysis, and the protocol presented in Reference [39] was used. Firstly, the cantilever spring constant was calculated using the Sader method (https: //sadermethod.org/). The range of the cantilever stiffness for all the probes used was between 116 and $200 \mathrm{~N} / \mathrm{m}$. The tip radius was then calibrated with a relative method using HOPG (highly oriented pyrolytic graphite, $18 \mathrm{GPa}$ indentation modulus, distributed by Bruker) and Kevlar fibers embedded in an epoxy resin (Epofix, Struers, Champigny sur Marne, France) previously measured by nanoindentation, having an indentation modulus around $20 \mathrm{GPa}$ [39]. The tip radius used was between 15 and $50 \mathrm{~nm}$ for all the probes. The maximum of the peak force setpoint used was set to $200 \mathrm{nN}$, with $2 \mathrm{kHz}$ peak force frequency, $40 \mathrm{kHz}$ Low Pass deflection BandWidth, and $75 \mathrm{~nm}$ peak force amplitude. A test to check the parameters was made on HOPG and Kevlar fiber/epoxy resin samples. For all measurements, 3-4 acquisitions were done with a verification of the value of the indentation modulus in the embedding resin of each sample. In all cases, since all the tested materials 
are stiff (more than a few GPa), the tip radius was quite small, the adhesion force was a few tens of nanoNewtons (lower than half the applied force setpoint), and the maximum indentation depth (e.g., of the order of $1 \mathrm{~nm}$ ) was small compared to the tip radius, we used a Derjaguin-Muller-Toporov (DMT) model (i.e., Hertz model including the effect of adhesion without any change in the contact behavior) [74] to process the force-distance curve and extract the indentation modulus.

Gwyddion software (Department of Nanometrology, Czech Metrology Institute, Brno, Czech Republic, http://gwyddion.net [75]) was used to process the images acquired. For each sample, at least three images of $512 \times 512$ pixels were used and several images of $256 \times 256$ pixels were acquired and considered to have good image representability and a statistically significant average. A small area of each image was selected according to the morphology of the middle lamella, and only the cell corner (tricellular junctions) was considered, as shown in Figure 8. A mean of the indentation modulus of the selected area was calculated by using the "statistical quantities" tool of the software.

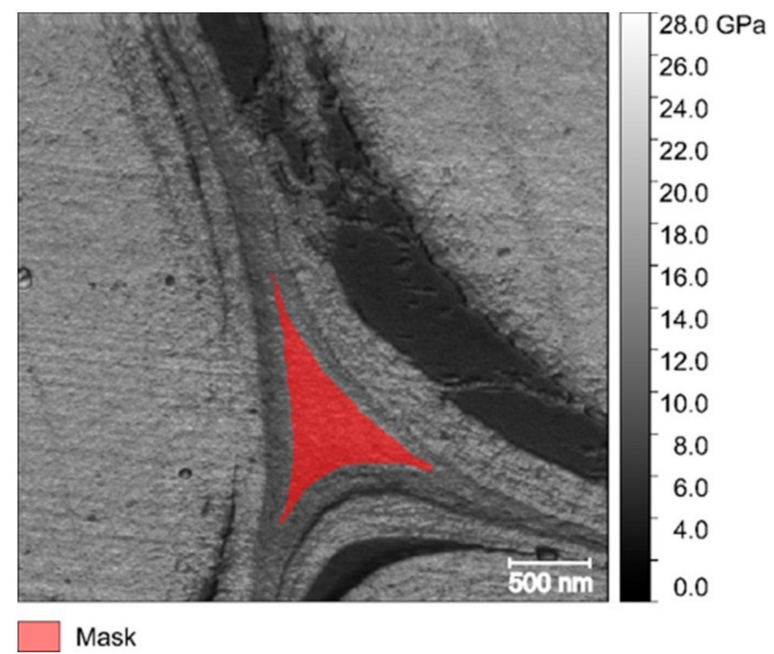

Figure 8. Flax middle lamella with a selected area mask to calculate the indentation modulus mean value and standard deviation.

\section{Conclusions}

The results obtained in this paper show differences in both the elastic mechanical behavior and the morphology of the middle lamellae in fiber bundles from six different plants commonly used as biocomposite reinforcements: flax, hemp, jute, kenaf, nettle, and date palm leaf sheath. Atomic force microscopy mechanical characterization mode (AFM PF-QNM) was used here as it is probably the only technique available today capable of providing semi-quantitative mechanical values of very thin layers at the nanoscale level, such as middle lamellae. This allowed us to propose a comparative database of the indentation modulus of the cell corner middle lamella of the six plant fibers considered with three different groups: the first one (flax, jute and kenaf) with intermediate indentation modulus (on average between 8 and $12 \mathrm{GPa}$ ) close to values already obtained in previous studies on wood fiber middle lamellae, the second one (hemp and nettle) with very high values (in average between 13 and 17 GPa), surprisingly close to those of the secondary cell wall, and the last one (date palm leaf sheath) with low values (in average between 6 and $9 \mathrm{GPa}$ ), close to the lowest values obtained on wood fiber middle lamella. Moreover, the sample topography highlights morphological differences and heterogeneities between the middle lamella, as well as the primary and the secondary wall structure, with, on the one hand, very clear sublayers in the case of flax, date palm leaf sheath, and jute and, on the other hand, hardly distinguishable sublayers in the case of hemp and nettle with an irregular matrix like a grid for the cell corner middle lamella and sometimes a strong globular or nodular aspect for the primary wall in the case of kenaf. The global biochemical composition or the origin and the role of each kind of fiber in its respective plant does not completely explain the different kind of CCML encountered 
here, and local biochemical analysis will be necessary for the future. Nevertheless, the present results give complementary information for future modeling of plant fiber bundles and the design of better performing biocomposites. In addition to the semi-quantitative values provided, our results open new perspectives for future studies on the natural variability of the bundle intra plant (in the same stem all along its height) and inter plant (comparing similar locations in different stem samples) properties.

Author Contributions: O.A. made the flax, kenaf and jute samples, carried out all the sample surface preparation, designed and contributed to the AFM experiments. A.M. made the nettle and hemp samples, carried out the AFM experiments and wrote the manuscript. All authors contributed to the analysis of the results, worked on the manuscript and approved it. A.B., O.A. and J.B. designed and supervised the research. All authors have read and agreed to the published version of the manuscript.

Funding: The INTERREG VA FCE Program, FLOWER project, Grant Number 23.

Acknowledgments: The authors want to thank the INTERREG VA FCE Program for funding this work through the FLOWER project. The Eco-Technilin company is also thanked for providing the jute and kenaf samples, as well as FRD for providing the nettle samples. Miss Anouck Habrant (INRA of Reims) is thanked for the initial preparation of date palm leaf sheat sample. Dr. Tancrède Alméras (University of Montpellier) and Dr. Frédéric Jamme (SOLEIL Synchrotron) are also thanked for fruitful discussions, as well as Miss Chloé Joly and Mr Anton Loïc Rudolph for the post-editing of English style and grammar.

Conflicts of Interest: The authors declare no conflicts of interest.

\section{Appendix A}

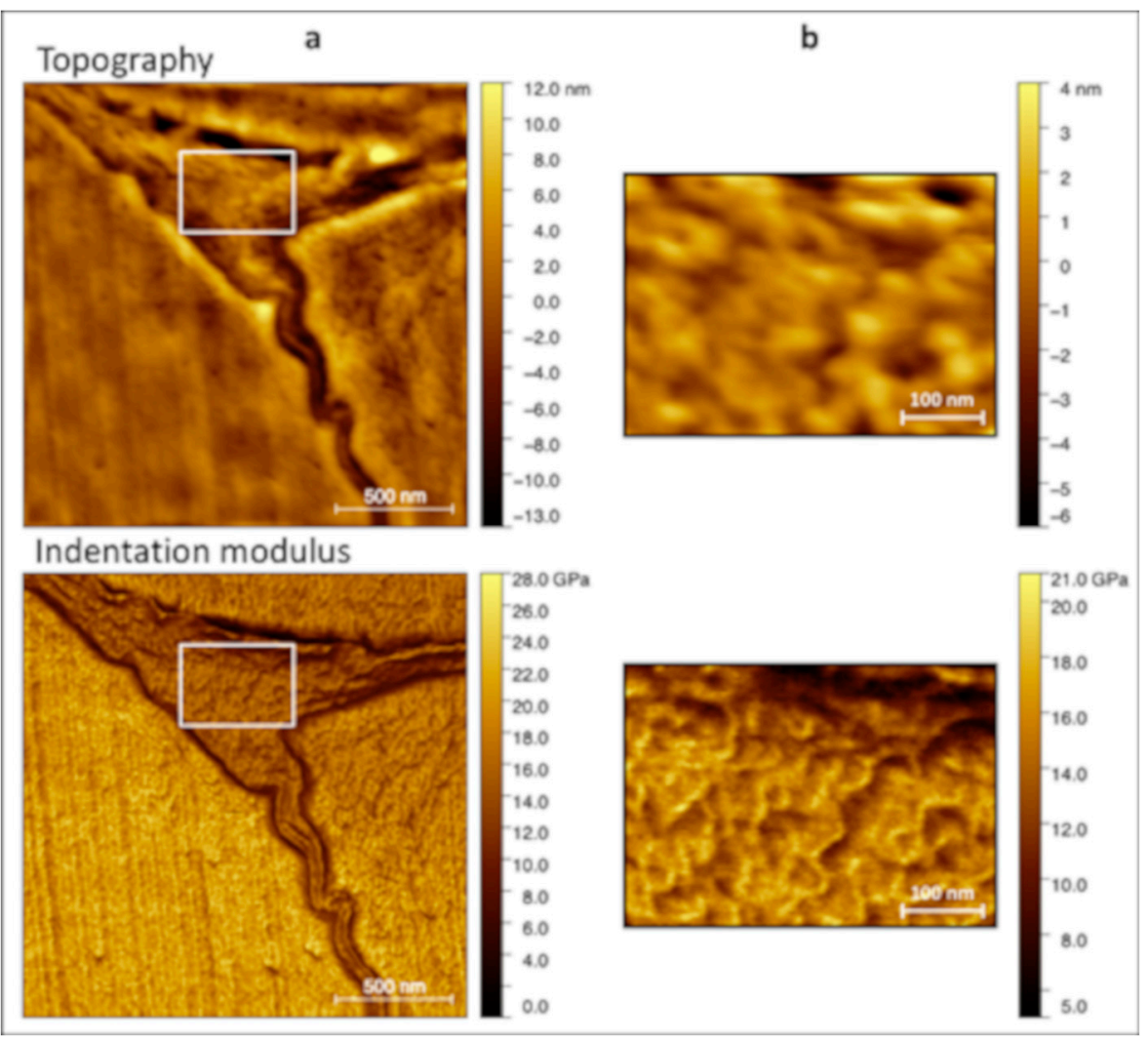

Figure A1. (a) Surface topography and indentation modulus of nettle corresponding to those reported in Figure 2. (b) Zoomed-in view of the ML region, corresponding to the white rectangle in (a), in order to highlight the correlation between topography and indentation modulus.

\section{References}

1. Merotte, J.; Le Duigou, A.; Bourmaud, A.; Behlouli, K.; Baley, C. Mechanical and acoustic behaviour of porosity controlled randomly dispersed flax/PP biocomposite. Polym. Test. 2016, 51, 174-180. [CrossRef] 
2. Pil, L.; Bensadoun, F.; Pariset, J.; Verpoest, I. Why are designers fascinated by flax and hemp fibre composites? Compos. Part A Appl. Sci. Manuf. 2015, 83, 193-205. [CrossRef]

3. Miao, M.; Finn, N. Conversion of natural fibres into structural composites. J. Text. Eng. 2008, 54, $165-177$. [CrossRef]

4. Kicińska-Jakubowska, A.; Bogacz, E.; Zimniewska, M. Review of natural fibers. Part I-Vegetable fibers. J. Nat. Fibers 2012, 9, 150-167. [CrossRef]

5. Duval, A.; Bourmaud, A.; Augier, L.; Baley, C. Influence of the sampling area of the stem on the mechanical properties of hemp fibers. Mater. Lett. 2011, 65, 797-800. [CrossRef]

6. Ansell, M.P.; Mwaikambo, L.Y. 2 - The structure of cotton and other plant fibres. In Handbook of Textile Fibre Structure: Natural, Regenerated, Inorganic and Specialist Fibres; Woodhead Publishing Limited: Cambridge, UK, 2009; Volume 2, pp. 62-94. ISBN 9781845697303.

7. Bourmaud, A.; Beaugrand, J.; Shah, D.U.; Placet, V.; Baley, C. Towards the design of high-performance plant fibre composites. Prog. Mater. Sci. 2018, 97, 347-408. [CrossRef]

8. Wambua, P.; Ivens, J.; Verpoest, I. Natural fibres: can they replace glass in fibre reinforced plastics? Compos. Sci. Technol. 2003, 63, 1259-1264. [CrossRef]

9. Graupner, N.; Labonte, D.; Humburg, H.; Buzkan, T.; Dörgens, A.; Kelterer, W.; Müssig, J. Functional gradients in the pericarp of the green coconut inspire asymmetric fibre-composites with improved impact strength, and preserved flexural and tensile properties. Bioinspir. Biomim. 2017, 12, 026009. [CrossRef]

10. Rihouey, C.; Paynel, F.; Gorshkova, T.; Morvan, C. Flax fibers: assessing the non-cellulosic polysaccharides and an approach to supramolecular design of the cell wall. Cellulose 2017, 24, 1985-2001. [CrossRef]

11. Rogers, K. The Cell; Britannica Educational Publications (in Association with Rosen Educational Services): New York, NY, USA, 2011; ISBN 978-1-61530-386-1.

12. Lazić, B.D.; Pejić, B.M.; Kramar, A.D.; Vukčević, M.M.; Mihajlovski, K.R.; Rusmirović, J.D.; Kostić, M.M. Influence of hemicelluloses and lignin content on structure and sorption properties of flax fibers (Linum usitatissimum L.). Cellulose 2018, 25, 697-709. [CrossRef]

13. Zamil, M.S.; Geitmann, A. The middle lamella-more than a glue. Phys. Biol. 2017, 14, 015004. [CrossRef] [PubMed]

14. Sfiligoj Smole, M.; Hribernik, S.; Stana Kleinschek, K.; Kreže, T. Plant Fibres for Textile and Technical Applications. In Advances in Agrophysical Research; Grundas, P.S., Ed.; IntechOpen Limited: London, UK, 2013; pp. 369-398.

15. Raghavan, R.; Adusumalli, R.-B.; Buerki, G.; Hansen, S.; Zimmermann, T.; Michler, J. Deformation of the compound middle lamella in spruce latewood by micro-pillar compression of double cell walls. J. Mater. Sci. 2012, 47, 6125-6130. [CrossRef]

16. Bourmaud, A.; Siniscalco, D.; Foucat, L.; Goudenhooft, C.; Falourd, X.; Pontoire, B.; Arnould, O.; Beaugrand, J.; Baley, C. Evolution of flax cell wall ultrastructure and mechanical properties during the retting step. Carbohydr. Polym. 2019, 206, 48-56. [CrossRef] [PubMed]

17. Siniscalco, D.; Arnould, O.; Bourmaud, A.; Le Duigou, A.; Baley, C. Monitoring temperature effects on flax cell-wall mechanical properties within a composite material using AFM. Polym. Test. 2018, 69, 91-99. [CrossRef]

18. Doumbia, A.S.A.S.; Castro, M.; Jouannet, D.; Kervoëlen, A.; Falher, T.; Cauret, L.; Bourmaud, A. Flax/polypropylene composites for lightened structures: Multiscale analysis of process and fibre parameters. Mater. Des. 2015, 87, 331-341. [CrossRef]

19. Bourmaud, A.; Ausias, G.; Lebrun, G.; Tachon, M.-L.L.; Baley, C. Observation of the structure of a composite polypropylene/flax and damage mechanisms under stress. Ind. Crops Prod. 2013, 43, 225-236. [CrossRef]

20. Monti, A.; El Mahi, A.; Jendli, Z.; Guillaumat, L. Mechanical behaviour and damage mechanisms analysis of a flax-fibre reinforced composite by acoustic emission. Compos. Part A Appl. Sci. Manuf. 2016, 90, 100-110. [CrossRef]

21. Beaugrand, J.; Guessasma, S.; Maigret, J.-E. Damage mechanisms in defected natural fibers. Sci. Rep. 2017, 7, 14041. [CrossRef]

22. Guessasma, S.; Beaugrand, J. Damage kinetics at the sub-micrometric scale in bast fibers using finite element simulation and high-resolution X-Ray micro-tomography. Front. Plant Sci. 2019, 10, 194. [CrossRef]

23. Zamil, M.S.; Yi, H.; Puri, V.M. Mechanical characterization of outer epidermal middle lamella of onion under tensile loading. Am. J. Bot. 2014, 101, 778-787. [CrossRef] 
24. Charlet, K.; Beakou, A. Interfaces within flax fibre bundle: Experimental characterization and numerical modelling. J. Compos. Mater. 2014, 48, 3263-3269. [CrossRef]

25. Qin, L.; Lin, L.; Fu, F.; Fan, M. Micromechanical properties of wood cell wall and interface compound middle lamella using quasi-static nanoindentation and dynamic modulus mapping. J. Mater. Sci. 2018, 53, 549-558. [CrossRef]

26. Jakes, J.E.; Frihart, C.R.; Beecher, J.F.; Moon, R.J.; Resto, P.J.; Melgarejo, Z.H.; Suárez, O.M.; Baumgart, H.; Elmustafa, A.A.; Stone, D.S. Nanoindentation near the edge. J. Mater. Res. 2009, 24, 1016-1031. [CrossRef]

27. Gindl, W.; Gupta, H.-S.; Schöberl, T.; Lichtenegger, H.-C.; Fratzl, P. Mechanical properties of spruce wood cell walls by nanoindentation. Appl. Phys. A 2004, 79, 2069-2073. [CrossRef]

28. Wimmer, R.; Lucas, B. Comparing mechanical properties of secondary and cell corner middle lamella in spruce wood. IAWA J. 1997, 18, 77-88. [CrossRef]

29. Arnould, O.; Arinero, R. Towards a better understanding of wood cell wall characterisation with contact resonance atomic force microscopy. Compos. Part A-Appl. Sci 2015, 74, 69-76. [CrossRef]

30. Clair, B.; Arinero, R.; Leveque, G.; Ramonda, M.; Thibaut, B. Imaging the mechanical properties of wood cell layers by atomic force modulation microscopy. IAWA J. 2003, 24, 223-230. [CrossRef]

31. Muraille, L.; Aguié-Béghin, V.; Chabbert, B.; Molinari, M. Bioinspired lignocellulosic films to understand the mechanical properties of lignified plant cell walls at nanoscale. Sci. Rep. 2017, 7, 44065. [CrossRef]

32. Ren, D.; Wang, H.; Yu, Z.; Wang, H.; Yu, Y. Mechanical imaging of bamboo fiber cell walls and their composites by means of peakforce quantitative nanomechanics (PQNM) technique. Holzforschung 2015, 69, 975-984. [CrossRef]

33. Eder, M.; Arnould, O.; Dunlop, J.W.C.; Hornatowska, J.; Salmen, L.; Salmén, L.; Salmen, L. Experimental micromechanical characterisation of wood cell walls. Wood Sci. Technol. 2013, 47, 163-182. [CrossRef]

34. Jäger, A.; Bader, T.; Hofstetter, K.; Eberhardsteiner, J. The relation between indentation modulus, microfibril angle, and elastic properties of wood cell walls. Compos. Part A Appl. Sci. Manuf. 2011, 42, 677-685. [CrossRef]

35. Malek, S.; Gibson, L.J. Multi-scale modelling of elastic properties of balsa. Int. J. Solids Struct. 2017, 113-114, 118-131. [CrossRef]

36. Bourmaud, A.; Mérotte, J.; Siniscalco, D.; Le Gall, M.; Gager, V.; Le Duigou, A.; Pierre, F.; Behlouli, K.; Arnould, O.; Beaugrand, J.; et al. Main criteria of sustainable natural fibre for efficient unidirectional biocomposites. Compos. Part A Appl. Sci. Manuf. 2019, 124, 105504. [CrossRef]

37. Dhakal, H.; Bourmaud, A.; Berzin, F.; Almansour, F.; Zhang, Z.; Shah, D.U.; Beaugrand, J. Mechanical properties of leaf sheath date palm fibre waste biomass reinforced polycaprolactone (PCL) biocomposites. Ind. Crops Prod. 2018, 126, 394-402. [CrossRef]

38. Goudenhooft, C.; Siniscalco, D.; Arnould, O.; Bourmaud, A.; Sire, O.; Gorshkova, T.; Baley, C. Investigation of the mechanical properties of flax cell walls during plant development: The relation between performance and cell wall structure. Fibers 2018, 6, 6. [CrossRef]

39. Arnould, O.; Siniscalco, D.; Bourmaud, A.; Le Duigou, A.; Baley, C. Better insight into the nano-mechanical properties of flax fibre cell walls. Ind. Crops Prod. 2017, 97, 224-228. [CrossRef]

40. Gao, J.; Kim, J.S.; Terziev, N.; Allegretti, O.; Daniel, G. Chemical and ultrastructural changes in compound middle lamella (CML) regions of softwoods thermally modified by the Termovuoto process. Holzforschung 2014, 68, 849-859. [CrossRef]

41. Abdul Khalil, H.P.S.; Yusra, A.F.I.; Bhat, A.H.; Jawaid, M. Cell wall ultrastructure, anatomy, lignin distribution, and chemical composition of Malaysian cultivated kenaf fiber. Ind. Crops Prod. 2010, 31, 113-121. [CrossRef]

42. Day, A.; Ruel, K.; Neutelings, G.; Crônier, D.; David, H.; Hawkins, S.; Chabbert, B. Lignification in the flax stem: Evidence for an unusual lignin in bast fibers. Planta 2005, 222, 234-245. [CrossRef]

43. Le Duigou, A.; Bourmaud, A.; Balnois, E.; Davies, P.; Baley, C. Improving the interfacial properties between flax fibres and PLLA by a water fibre treatment and drying cycle. Ind. Crops Prod. 2012, 39, 31-39. [CrossRef]

44. Bourmaud, A.; Gibaud, M.; Lefeuvre, A.; Morvan, C.; Baley, C. Influence of the morphology characters of the stem on the lodging resistance of Marylin flax. Ind. Crops Prod. 2015, 66, 27-37. [CrossRef]

45. Radotić, K.; Simić-Krstić, J.; Jeremić, M.; Trifunović, M. A study of lignin formation at the molecular level by scanning tunneling microscopy. Biophys. J. 1994, 66, 1763-1767. [CrossRef] 
46. Terashima, N.; Awano, T.; Takabe, K.; Yoshida, M. Formation of macromolecular lignin in ginkgo xylem cell walls as observed by field emission scanning electron microscopy. C. R. Biol. 2004, 327, 903-910. [CrossRef] [PubMed]

47. Stan, G.; Cook, R.F. Mapping the elastic properties of granular Au films by contact resonance atomic force microscopy. Nanotechnology 2008, 19, 235701. [CrossRef] [PubMed]

48. Hanley, S.J.; Gray, D.G. Atomic force microscope images of black spruce wood sections and pulp fibres. Holzforschung 1994, 48, 29-34. [CrossRef]

49. Kundu, A.; Sarkar, D.; Mandal, N.A.; Sinha, M.K.; Mahapatra, B.S. A secondary phloic (bast) fibre-shy (bfs) mutant of dark jute (Corchorus olitorius L.) develops lignified fibre cells but is defective in cambial activity. Plant Growth Regul. 2012, 67, 45-55. [CrossRef]

50. Daher, F.B.; Braybrook, S.A. How to let go: pectin and plant cell adhesion. Front. Plant Sci. 2015, 6, 523. [CrossRef]

51. Bourmaud, A.; Dhakal, H.; Habrant, A.; Padovani, J.; Siniscalco, D.; Ramage, M.H.; Beaugrand, J.; Shah, D.U. Exploring the potential of waste leaf sheath date palm fibres for composite reinforcement through a structural and mechanical analysis. Compos. Part A Appl. Sci. Manuf. 2017, 103. [CrossRef]

52. Baley, C.; Perrot, Y.; Busnel, F.; Guezenoc, H.; Davies, P. Transverse tensile behaviour of unidirectional plies reinforced with flax fibres. Mater. Lett. 2006, 60, 2984-2987. [CrossRef]

53. Coroller, G.; Lefeuvre, A.; Le Duigou, A.; Bourmaud, A.; Ausias, G.; Gaudry, T.; Baley, C. Effect of flax fibres individualisation on tensile failure of flax/epoxy unidirectional composite. Compos. Part A Appl. Sci. Manuf. 2013, 51, 62-70. [CrossRef]

54. Barthelat, F.; Espinosa, H.D. An experimental investigation of deformation and fracture of nacre-Mother of pearl. Exp. Mech. 2007, 47, 311-324. [CrossRef]

55. Tanguy, M.; Bourmaud, A.; Beaugrand, J.; Gaudry, T.; Baley, C. Polypropylene reinforcement with flax or jute fibre; Influence of microstructure and constituents properties on the performance of composite. Compos. Part B Eng. 2018, 139, 64-74. [CrossRef]

56. Graupner, N.; Fischer, H.; Ziegmann, G.; Müssig, J. Improvement and analysis of fibre/matrix adhesion of regenerated cellulose fibre reinforced PP-, MAPP- and PLA-composites by the use of Eucalyptus globulus lignin. Compos. Part B Eng. 2014, 66, 117-125. [CrossRef]

57. Padovani, J.; Legland, D.; Pernes, M.; Gallos, A.; Thomachot-Schneider, C.; Shah, D.U.; Bourmaud, A.; Beaugrand, J. Beating of hemp bast fibres: an examination of a hydro-mechanical treatment on chemical, structural, and nanomechanical property evolutions. Cellulose 2019, 26, 5665-5683. [CrossRef]

58. Berzin, F.; Beaugrand, J.; Dobosz, S.; Budtova, T.; Vergnes, B. Lignocellulosic fiber breakage in a molten polymer. Part 3. Modeling of the dimensional change of the fibers during compounding by twin screw extrusion. Compos. Part A Appl. Sci. Manuf. 2017, 101, 422-431. [CrossRef]

59. Le Duc, A.; Vergnes, B.; Budtova, T. Polypropylene/natural fibres composites: Analysis of fibre dimensions after compounding and observations of fibre rupture by rheo-optics. Compos. Part A Appl. Sci. Manuf. 2011, 42, 1727-1737. [CrossRef]

60. Alix, S.; Lebrun, L.; Marais, S.; Philippe, E.; Bourmaud, A.; Baley, C.; Morvan, C. Pectinase treatments on technical fibres of flax: Effects on water sorption and mechanical properties. Carbohydr. Polym. 2012, 87, 177-185. [CrossRef]

61. Biagiotti, J.; Puglia, D.; Kenny, J.M. A Review on natural fibre-based composites-Part I: Structure, processing and properties of vegetable fibres. J. Nat. Fibers 2004, 1, 37-68. [CrossRef]

62. Van Hazendonk, J.M.; Reinerik, E.J.M.; de Waard, P.; van Dam, J.E.G. Structural analysis of acetylated hemicellulose polysaccharides from fibre flax (Linum usitatissimum L.). Carbohydr. Res. 1996, 291, 141-154. [CrossRef]

63. Esau, K. Plant Anatomy; Wiley: New York, NY, USA, 1953.

64. Crônier, D.; Monties, B.; Chabbert, B. Structure and chemical composition of bast fibers isolated from developing hemp stem. J. Agric. Food Chem. 2005, 53, 8279-8289. [CrossRef]

65. Marrot, L.; Lefeuvre, A.; Pontoire, B.; Bourmaud, A.; Baley, C. Analysis of the hemp fiber mechanical properties and their scattering (Fedora 17). Ind. Crops Prod. 2013, 51. [CrossRef]

66. Gümüşkaya, E.; Usta, M.; Balaban, M. Carbohydrate components and crystalline structure of organosolv hemp (Cannabis sativa L.) bast fibers pulp. Bioresour. Technol. 2007, 98, 491-497. [CrossRef] [PubMed] 
67. Khan, F.; Ahmad, S.R. Chemical modification and spectroscopic analysis of jute fibre. Polym. Degrad. Stab. 1996, 52, 335-340. [CrossRef]

68. Roy, A.; Chakraborty, S.; Kundu, S.P.; Basak, R.K.; Majumder, S.B.; Adhikari, B. Improvement in mechanical properties of jute fibres through mild alkali treatment as demonstrated by utilisation of the Weibull distribution model. Bioresour. Technol. 2012, 107, 222-228. [CrossRef]

69. Karimi, S.; Tahir, P.M.; Karimi, A.; Dufresne, A.; Abdulkhani, A. Kenaf bast cellulosic fibers hierarchy: A comprehensive approach from micro to nano. Carbohydr. Polym. 2014, 101, 878-885. [CrossRef]

70. Ashori, A.; Harun, J.; Raverty, W.D.; Yusoff, M.N.M. Chemical and morphological characteristics of Malaysian cultivated kenaf (Hibiscus cannabinus) fiber. Polym. Plast. Technol. Eng. 2006, 45, 131-134. [CrossRef]

71. Zhou, C.; Ohtani, Y.; Sameshima, K.; Zhen, M. Selection of plant population of kenaf (Hibiscus cannabinus L.) as a papermaking raw material on arid hillside land in China. J. Wood Sci. 1998, 44, 296-302. [CrossRef]

72. Bacci, L.; Di Lonardo, S.; Albanese, L.; Mastromei, G.; Perito, B. Effect of different extraction methods on fiber quality of nettle (Urtica dioica L.). Text. Res. J. 2011, 81, 827-837. [CrossRef]

73. Saadaoui, N.; Rouilly, A.; Fares, K.; Rigal, L. Characterization of date palm lignocellulosic by-products and self-bonded composite materials obtained thereof. Mater. Des. 2013, 50, 302-308. [CrossRef]

74. Derjaguin, B.V.; Muller, V.M.; Toporov, Y.P. Effect of contact deformations on the adhesion of particles. J. Colloid Interface Sci. 1975, 53, 314-326. [CrossRef]

75. Nečas, D.; Klapetek, P. Gwyddion: An open-source software for SPM data analysis. Open Phys. 2012, 10, 181-188. [CrossRef]

Sample Availability: Samples are available from the authors.

(C) 2020 by the authors. Licensee MDPI, Basel, Switzerland. This article is an open access article distributed under the terms and conditions of the Creative Commons Attribution (CC BY) license (http://creativecommons.org/licenses/by/4.0/). 